\title{
THE DISTRIBUTION OF OLIGOCHAETES IN THE HARINGVLIET. HOLLANDS DIEP (DELTA REGION OF THE NETHERLANDS) BEFORE AND AFTER THE CLOSURE IN 1970
}

\author{
PIET F.M. VERDONSCHOT *
}

(Delta Institute for Hydriobiological Research, Vierstraat 28, 4401 EA Yerseke, the Netherlands)

\section{(SUMMARY)}

Samples, collected from 1959 to 1970 , were used to describe the distribution and ecology of some oligochaetes in the Delta region. In the brackish and marine parts of the estuary the following species were found; Tubifex costatus, T. pseudogaster, Peloscolex benedeni and Monopylephorus rubroniveus. The other identified species were more or less euryhaline-freshwater organisms. The distribution pattern of these species was correlated with salinity and sediment. The species had a wider chlorinity tolerance than reported in the literature. The preference of Peloscolex benedeni for clay sediments was due to low oxygen or hydrogensulfide conditions in the sediment. Limnodrilus hoffmeisteri preferred well sorted muddy sand bottoms and $L$. udekemianus less well sorted clay bottoms. Tubifex costatus occurred abundantly in intertidal regions. The occurrence of most of the collected oligochaetes was positively correlated with the quantity of organic matter in the sediment.

An investigation carried out from 1971 to 1977 to study the development of the macrofaunal community in the fresh Haringvliet-Hollands Diep basin after closure of this basin showed a mass development of Tubificidae. This was related to the high organic matter content in the bottom and the high colonization and reproductive capacity of these worms.

It appeared that several species of tubificids coexisted for several years in the same habitat at a roughly constant relative abundance.

Several investigators showed a selective feeding of tubificids on certain groups of bacteria. A niche delimitation probably exists through the nature of the food used by these tubificids.

A detailed account of the results presented here will be given elsewhere.

- Present address: Provincial Water Authority, P.O.Box 73,8000 AB Zwolle, the Netherlands

\section{ECOLOGICAL INVESTIGATIONS IN SUBLITTORAL BIOCENOSES ON HARD SUBSTRATES}

\section{H.W.WAARDENBURG}

(Bureau Waardenburg bv, Achterstraat 26, Culemborg, the Netherlands)

\section{(SUMMARY)}

In 1979 the Environment Research Division of the Delta Service of the Dutch Department of Public Works and Waterways instructed Bureau Waardenburg to investigate the distribution of biocenoses on and near hard substrates in the Eastern Scheldt and Lake Grevelingen. The instruction was issued in connection with the progress of the so-called 'Delta Works', a large engineering project aiming at a maximal protection of the southwest Netherlands against stormfloods. In this project dykes are made higher, some estuaries have been closed off from the sea, and the Eastern Scheldt area will be protected by means of a storm surge barrier.

The intention of the investigation presented here is to describe the biocenoses of the hard substrates in such a way, that changes caused by the engineering project can be established.

This means that these biocenoses must be described in terms of a list of species visible to the naked eye, of which the percentage of coverage of the substrate is estimated.

Is is attempted to obtain an impression of seasonal changes in the biocenoses, and to distinguish these from phenomena that are not connected with the seasonal changes. Diatoms, microscopical algae, small crustaceans (like Gammaridea) and worms and molluscs which normally live in concealment were not studied. Underwater observations in this investigation are done by divers with SCUBA equipment. In winter and spring, when water temperatures are low, dry constant-volume diving suits are being used.

Apart from stony materials also wood and peat are studied because of their suitability as settling substrate for various organisms. Three times a year, in February-March, June-July, and October-November, 